\title{
A Novel Rhizospheric Bacterium, Bacillus Velezensis NKMV-3 as a Biocontrol Agent against Alternaria Leaf Blight in Tomato
}

Vignesh Murthy ( $\square$ nanovignesh@gmail.com )

Bharathiar University

\section{VedhaHari BodethalaNarayanan}

SASTRA Deemed University: Shanmugha Arts Science Technology and Research Academy

\section{MubarakAli Davoodbasha}

B S Abdur Rahman Crescent Institute of Science \& Technology

\section{MadhanShankar ShankarRamakrishanan}

Kongunadu Arts and Science College

\section{Research Article}

Keywords: Biocontrol, Bacillus velezensis, Early Blight, Alternaria solani, Lipopeptide

Posted Date: August 3rd, 2021

DOl: https://doi.org/10.21203/rs.3.rs-755736/v1

License: (a) (i) This work is licensed under a Creative Commons Attribution 4.0 International License. Read Full License 


\section{Abstract}

A novel strain of Bacillus isolated from rhizosphere has shown to be excellent biocontrol agents against various plant pathogens. In this study, a first report of a Bacillus strain NKMV-3 which effectively controlling Alternaria solani, which cause the Early Blight disease in tomato. Based on the cultural and molecular sequencing of 16S rRNA gene sequence, the identity of the strain was confirmed as Bacillus velezensis NKMV-3. The presence of the lipopeptide which are antibiotic synthesis genes namely Iturin C, Surfactin A, Fengycin B and D were confirmed through gene amplification. In addition, lipopetides was also confirmed through liquid chromatography. The extract showed inhibitory effect against $A$.solani invitro and detached tomato leaf assays. Bacillus velezensis strain NKMV-3 based formulations may provide an effective solution in controlling early blight disease in tomato and other crops.

\section{Introduction}

Tomato (Solanum lycopersicum Linn.), is one of the most important crops cultivated throughout the world in a wide range of climates among solanaceous crops $[1,2]$. Tomato is ranked as the second most consumed vegetable after potato due to its rich source of vitamin $\mathrm{A}, \mathrm{C}$ and $\mathrm{K}$, minerals aminoacids and antioxidants, lycopene[2, 3]. There is a high demand because of its wide use and nutritional values, both in fresh and processed tomato markets. Therefore, higher production is required to fulfil the increasing demandand for value addition. The tomato cultivation is mainly hindered by bacterial, fungal and viral diseases[4]. The early blight caused by Alternaria solani, in particular severely affects the tomato production $[4,5]$. A. solani is an air-borne pathogen inhabiting the soil. It is distributed worldwide, but is highly infective in the tropics and temperate regions[5]. Synthetic fungicides such as mancozeb, pyraclostrobin, azoxystrobin and hexaconazole are utilized for the control of this disease in various crops $[6,7]$. However, $A$. solani is gaining resistance to these pesticides and causing serious problems in the yield of tomatoes[8, 9].

Over the past few decades, chemical pesticides have been extensively used by farmers for crop protection, but it posessevere adverseenvironmental and detrimental healtheffects[10, 11]. Unscrupulous usage of fungicides encourage in the development of resistant pest/pathogen strains,destruction of nontarget organisms, leads to residual toxicity, and other health and ecological hazards[12-14]. Thus, alternative eco-friendly sustainable agricultural practices like adopting tomicrobial control of pests and diseases is the need of the hour. Bacterial biocontrol agentshaverecently gained worldwide attention for the control of various plant pathogens due to their low cost and ease of production, environment friendliness and non-residual effect $[15,16]$.Many species of the genus Bacillus are potential candidates for development as biocontrol agents against various plant pathogens.[17, 18]. Among Bacillus spp., $B$. velezensis is one of the potential biocontrol agent $[19,20]$. Literature reports numerousstrains of $B$. velezensis strains capable of controlling the major plant pathogens (bacteria \& fungi) and nematodes[19-23]. 
In the present study, bacterial strains were isolated from soil samples collected from the roots of tomato plants and screened in vitro for antagonistic activity against $A$. solani.B. velezensis was identified by 16srRNA sequencing. Through FTIR and RP-HPLC analyses, the antifungal lipopeptides secreted by $B$. velezensis were characterized and its efficacy against $A$. solani were studied by poison food technique and detached leaf assays.

\section{Materials And Methods}

Isolation of Antagonistic bacteria and Alternaria solani causing Early Blight in Tomato

The sampling was conductedduring the months of September to November 2019 in 20 locations of Tamil Nadu known for growing tomato crop in large acreages. Tomato growing fields were selected for sampling soil for the isolation antagonistic bacteria against early blight pathogen, Alternaria solani. Healthy tomato plants were uprooted carefully without disturbing the roots. Soil adhering to the roots was shaken and removed into poly Ziplock bags and immediately kept on ice until further processing.

\section{Isolation of putative antagonistic Bacillus isolates}

Soil samples collected from various tomato fields were removed from the cold storage and thawed to room temperature. A soil suspension was prepared using $10 \mathrm{~g}$ of each sample and $90 \mathrm{ml}$ of sterile water. The solution was agitated using a rotary shaker at $180 \mathrm{rev} \mathrm{min}^{-1}$ for 30 minutes. The suspensions thus prepared using all the soil samples were heated to $60^{\circ} \mathrm{C}$ for one hour and cooled immediately by placing in an ice box giving a heat shock reaction for the formation of endospores. The suspensions were serially diluted up to $10^{4}$ and spread plated on nutrient agar medium, followed by incubation at $30^{\circ} \mathrm{C}$ for 2 days in an incubator. Single colonies isolated were maintained as purified cultures on nutrient agar slants [24]. Purified putative antagonistic Bacillus isolates were stored at $-80^{\circ} \mathrm{C}$ in $60 \%$ glycerol stocks.

\section{Screening of putative antagonistic Bacillus isolates against various plant pathogens}

Putative antagonistic Bacillus isolates were subjected to screening through dual culture technique[25] against major pathogens of crops namely Fusarium oxysporum f.sp.lycopersici, Alternaria solani, Rhizoctonia solani, Macrophomina phaseolina and Pyricularia oryzae. All the phytopathogens were supplied by the Microbial Type Culture Collection culture (MTCC) bank, Chandigarh, India. Briefly, 5mm mycelial plug was removed from an actively growing plate of each phytopathogen and placed at one edge of the plate. Putative Bacillus isolates were streaked on other side of the mycelial plug near the edges of the plate followed by incubation at $28^{\circ} \mathrm{C}$ in an incubator for 7-10 days. Bacillus isolates which showed antagonistic activity through zone of inhibitions were selected. The percentage growth inhibition was calculated as per the below formula adapted from [26].

Inhibition $(\%)=[($ Control-Treatment $) /$ Control $] \times 100$ 
Where Control is the colony diameter in Control plates and Treatment is the colony diameter in treatment plates. The experiment was performed in triplicates.

\section{Characterization And Identification Of Putative Antagonistic Bacillus Isolates}

The putative antagonistic Bacillus isolate (NKMV-3) that was shortlisted through dual plate screening was characterized according to Bergey's manual of systematic Bacteriology [27] and using Himedia'sHiBacillus ${ }^{\mathrm{TM}}$ identification Kit. In order to identify the putative antagonistic Bacillus isolate, a loop full culture of NKMV-3 growing on Nutrient Agar was used for DNA extraction. Quick DNAFungal/Bacterial Miniprep Kit ofZymo Research was used for extracting DNA from the putative antagonistic Bacillus isolate (NKMV-3). 16S rRNA sequence of the extracted DNA was amplified throughPolymerase Chain Reaction (PCR) with two bacterial universal primers namely 27F (5'AGAGTTTGATCCTGGCTCAG-3') and 1492R (5'-GGTTACCTTGTTACGACTT-3')[28]. A 14 $\mu$ LPCR reaction mixture consisting of $8 \mu \mathrm{L}$ Taq Master mix, $2 \mu \mathrm{L}$ of each forward and reverse primers, $2 \mu \mathrm{L}$ of DNA template and $2 \mu \mathrm{L}$ of molecular grade water was used for amplifying the DNA. PCR was performed in an Eppendorf Mastercycler X50s. The PCR conditions were adapted from Zhu et al., 2020 with slight modifications as described: 1 minute of Initial denaturation at $95^{\circ} \mathrm{C}$, followed by 35 cycles of denaturation at $95^{\circ} \mathrm{C}$ for 30 seconds, 1 minute of annealing at $52^{\circ} \mathrm{C}$ followed by extension at $72^{\circ} \mathrm{C}$ for 2 minutes and 30 seconds. A final extension of $72^{\circ} \mathrm{C}$ for 10 minutes completed the PCR reaction. The PCR products were purified and sequenced by external sequencing facility. The sequencing results were compared with known bacterial NCBI Genbank sequences using BLAST and the identity was confirmed. The identified bacterial sequence was submitted with $\mathrm{NCBI}$ and an accession number was obtained. Mega 11 software was used for constructing a phylogenetic tree using the neighbor-joining method with 100 bootstrap replicates[30].

\section{Effect of crude lipopeptides against Alternaria solani}

The effect of the crude lipopeptides obtained from NKMV-3 was tested through a modified poison food technique[31]. The dried crude lipopeptide powder was used for preparing various concentrations starting from $1-5 \%$ in potato dextrose agar medium on W/V basis. Media containing various concentrations of the crude lipopeptides was autoclaved and dispensed in petri plates. After solidification, a $5 \mathrm{~mm}$ disc from an actively growing $A$.solani plate was extracted using a sterile cork borer and placed at the centre of the plate. The PDA plates containing no crude lipopeptides served as control for the trial. The plates were incubated at $28^{\circ} \mathrm{C}$ for 7 days in an incubator. After 7 days, the plates were observed for the growth of A.solani. The inhibition rate of mycelial growth was calculated as follows.

Inhibition rate $(\%)=$ [Diameter of colony in Control $(\mathrm{mm})$ - Diameter of colony in treatment $(\mathrm{mm}) /$ Diameter of colony in Control $(\mathrm{mm})] \times 100$

The experiment was conducted in triplicates. 


\section{Molecular Detection Of Surfactin, Fengycin And Iturin Genes}

A loop full of culture from an actively growing slant of NKMV-3 was used for DNA extraction. DNA was extracted as mentioned in the previous section of this article. Each PCR reaction was performed in an Eppendorf Mastercycler X50s thermal cycler using a $14 \mu \mathrm{L}$ reaction mixture containing Taq Master mix $(8 \mu \mathrm{L})$, forward and reverse primers $(2 \mu \mathrm{L}$ each), Molecular grade water $(2 \mu \mathrm{L})$. The primers were chosen from already available literature. The details of primers and expected amplicon sizes are provided in Table 1.The PCR conditions were adapted from [32,33] with slight modifications. Briefly, SfrA gene was amplified using a 35 -cycle reaction consisting of 4 minutes of initial denaturation at $95^{\circ} \mathrm{C}$, followed by denaturation for 1 minute at $94^{\circ} \mathrm{C}$. Annealing was performed at $52^{\circ} \mathrm{C}$ for $30 \mathrm{sec}$, followed by an extension at $70^{\circ} \mathrm{C}$ for 1 minute. A final extension was performed at $70^{\circ} \mathrm{C}$ for 5 minutes. fen $\mathrm{B}$, fen $\mathrm{D}$ and Itu $\mathrm{C}$ genes were amplified using a 40-cycle reaction consisting of 3 minutes of initial denaturation at $94^{\circ} \mathrm{C}$, followed by denaturation for 1 minute at $94^{\circ} \mathrm{C}$. Annealing was performed at $59^{\circ} \mathrm{C}$ (fen $\left.\mathrm{B}\right), 50^{\circ} \mathrm{C}$ (fen $\mathrm{D}$ \&/tu $\left.\mathrm{C}\right)$ for 1 minute, followed by an extension at $70^{\circ} \mathrm{C}$ for 1 minute. A final extension was performed at $72^{\circ} \mathrm{C}$ for 10 minutes. The PCR amplicons were analysed through gel electrophoresis on a $1 \%$ agarose run at constant voltage of $100 \mathrm{~V}$ for 40 minutes followed visualization using a gel documentation system (make: Vilber Quantum).

\section{Extraction Of Extracellular Metabolites Produced By Nkmv-3}

NKMV-3 was grown in Nutrient brothfor 72 hoursat $37^{\circ} \mathrm{Cin}$ a rotatory shaker with constant shaking of 130 rotations $\mathrm{min}^{-1}$. The cells were harvested after 3 days by centrifugation at 6,000 x gfor 15 minutes followed by the reduction of $\mathrm{pH}$ of the cell free extract to 2.0 by the addition of $3 \mathrm{~N} \mathrm{HCl}$ and left for overnight precipitation at $4^{\circ} \mathrm{C}$. The so precipitated crude lipopeptides was separated by centrifugation at $8,000 \times g$ for 30 minutes at $4^{\circ} \mathrm{C}$. The pellet was dissolved in methanol and extracted thrice and evaporated under vacuum using a rotatory evaporator at $50^{\circ} \mathrm{C}$ and $65 \mathrm{rpm}[34,35]$. The resulting viscous liquid was left for drying at $50^{\circ} \mathrm{C}$ for 48 hours in a hot air oven. The dried crude lipopeptide extract was scrapped and dissolved in Tris $\mathrm{HCl}$ pH 7.5 and stored until further use. 
Table 1

PCR Details for amplification of AMP genes

\begin{tabular}{|c|c|c|c|c|}
\hline S.No & Gene & Primer & Primer sequence & $\begin{array}{l}\text { Expected base pairs } \\
\text { (bp) }\end{array}$ \\
\hline \multirow[t]{2}{*}{1} & \multirow[t]{2}{*}{ SfrA } & \multirow[t]{2}{*}{ SRFA-F1/SRFA-R1 } & 5'-AGAGCACATTGAGCGTTACAAA-3' & \multirow[t]{2}{*}{670} \\
\hline & & & 5'-CAGCATCTCGTTCAACTTTCAC-3' & \\
\hline \multirow[t]{2}{*}{2} & \multirow[t]{2}{*}{$\begin{array}{l}\text { fen } \\
\mathrm{B}\end{array}$} & \multirow[t]{2}{*}{$\begin{array}{l}\text { FEN B-F1/ FEN B- } \\
\text { R1 }\end{array}$} & $\begin{array}{l}5^{\prime}- \\
\text { CCTGGAGAAAGAATATACCGTACCY- } \\
3^{\prime}\end{array}$ & \multirow[t]{2}{*}{670} \\
\hline & & & 5'-GCTGGTTCAGTTKGATCACAT-3' & \\
\hline \multirow[t]{2}{*}{3} & \multirow{2}{*}{$\begin{array}{l}\text { fen } \\
\text { D }\end{array}$} & \multirow{2}{*}{$\begin{array}{l}\text { FEN D-F1/ FEN D- } \\
\text { R1 }\end{array}$} & 5'-GGCCCGTTCTCTAAATCCAT-3' & \multirow[t]{2}{*}{670} \\
\hline & & & 5'-GTCATGCTGACGAGAGCAAA-3' & \\
\hline \multirow[t]{2}{*}{4} & \multirow[t]{2}{*}{ Itu $C$} & ITU C - F1/ & 5'-CCCCCTCGGTCAAGTGAATA-3' & \multirow[t]{2}{*}{594} \\
\hline & & ITU C - R1 & 5'-TTGGTTAAGCCCTGATGCTC-3' & \\
\hline
\end{tabular}

\section{Identification and quantification of Iturin, Surfactin and Fengycin in crude Lipopeptides using Liquid Chromatography}

All solvents used were of HPLC grade (Merck) and standards of Iturin, Surfactin and Fengycin were purchased from Sigma, USA. Crude lipopeptides were quantified by Reverse-Phase High performance liquid chromatography using a chromatograph (Waters, USA) equipped with a quartinary pump and diode array detector. Analytical scale Purospher ${ }^{\circledR}$ RP-C18 $(250 \times 4.6 \mathrm{~mm}, 5 \mu \mathrm{m}$ particle size $)$ column was used. $1 \mathrm{mg} / \mathrm{ml}$ of crude lipopeptide was prepared and filtered and filled into HPLC vials for injection. A volume of $2 \mu \mathrm{l}$ of sample was injected into the column. The mobile phase and chromatographic conditions were adapted from[36]. This method provided a single protocol for the detection and quantification of lipopeptides in a combined method rather than the conventional method of separate chromatographic runs for the identification and quantification of individual lipopeptides. The mobile phase consisted of Milli-Q Water (Solvent A) and 0.1\% HPLC grade trifluoroacetic acid dissolved in Acetonitrile(Solvent B). The elution of lipopeptide homologues was monitored at $210 \mathrm{~nm}$. The conditions of the chromatography are provided in Table 2. 
Table 2

Details for HPLC gradient conditions for the isolation and quantification of lipopeptides

\begin{tabular}{|llll|}
\hline Time (min) & Solvent A (\%) & Solvent B (\%) & $\begin{array}{l}\text { Flow rate } \\
\left(\mathrm{mL} \min ^{1}\right)\end{array}$ \\
\hline $0-4$ & 60 & 40 & 2 \\
\hline $4-11$ & 55 & 45 & 2 \\
\hline $11-17$ & 40 & 60 & 0.8 \\
\hline $17-22$ & 30 & 70 & 0.4 \\
\hline $22-30$ & 15 & 85 & 1.5 \\
\hline $30-33$ & 5 & 95 & 1.0 \\
\hline $33-35$ & 60 & 40 & 2 \\
\hline
\end{tabular}

Analysis of crude Lipopeptides through Fourier Transformation Infra-Red (FTIR) spectroscopy

The crude methanolic lipopeptide extract was subjected to a FTIR analysis (make:Perkin Elmer) to elucidate the structural groups of the crude lipopeptides. $100 \mathrm{mg}$ of $\mathrm{KBr}$ and an $\mathrm{mg}$ of crude lipopeptide extractof NKMV-3were ground using a pestle and pressed with load for $30 \mathrm{~s}$ to obtain translucent pellets. These pellets were subjected to FTIR between a frequency range from 4000 to $400 \mathrm{~cm}-1$ [37].

\section{Detached leaf bioassays of crude lipopeptides against A.solani in Tomato}

Detached leaf bioassays were conducted with slight modifications as described by [38]. Briefly, Tomato (Variety: PKM - 1) leaves from 45 days old potted plants were obtained. The leaves were surface sterilized using $1 \%$ sodium hypochlorite solution, followed by two washes with sterile water. The leaves were left for air drying inside the Laminar air flow chamber. Various concentrations of crude lipopeptides were prepared from $1-5 \%$ on W/V basis in sterile water and methanol in the ratio of 9:1. Using a handheld atomizer, the leaves were sprayed on both sides with the test solution. Untreated controls were maintained which were sprayed with only sterile water and methanol in the ratios as mentioned above. Control leaves with sterile water spray alone were also maintained. All the leaves were left to air dry inside the laminar air flow chamber. Upon drying, a $5 \mathrm{~mm}$ disc from an actively growing 7 days old $A$. solani plate was cut and place in the centre of each leaf, except for the untreated control leaves. All the leaves were placed on wet cotton inside petri dishes followed by incubation for 7 days at $28^{\circ} \mathrm{C}$ in an incubator. After 7 days the leaves were examined for lesions and the extent of lesion formation was measured in centimetres. The inhibition rate was calculated as follows

Inhibition rate $(\%)=$ [Diameter of lesion in Control $(\mathrm{cm})$ - Diameter of lesion in treatment $(\mathrm{cm}) /$ Diameter of lesion in Control $(\mathrm{cm})] \times 100$ 
The experiment was conducted in triplicates and statistically analysed.

\section{Statistical analysis}

All data was analysed statistically using WASP - Web Agri Stat Package 2.0 and Microsoft excel (2016) to assess statistically significant differences among the various treatments.

\section{Results}

Isolation of antagonistic bacteria against A.solanicausing early blight in tomato.

In this study, a total of 146 morphologically distinct isolates of bacteria were isolated from 20 different locations covering three major districts in Tamil Nadu (Salem, Krishnagiri and Dharmapuri) known for the production of Tomato (Table 3). Of the 146 strains screened by dual culture technique(data not shown), NKMV-3 showed maximum inhibition against $A$. solani.Based on this result we further explored the biocontrol potential of NKMV-3. 
Table 3

Locations of soil sample collectionacross major tomato growing districts of Tamil Nadu

\begin{tabular}{|llll|}
\hline S.No & Location & GPS coordinates & District Name \\
\hline 1 & Omalur & $11.744409995997248,78.04702812571645$ & Salem \\
\hline 2 & ChinnaThirupathi & $11.68502179676408,78.16517791092896$ & Salem \\
\hline 4 & Karuvalli & $11.853092036241849,78.02571765381492$ & Salem \\
\hline 5 & Kakapalayam & $11.562937807350007,78.02687110824542$ & Salem \\
\hline 6 & Mechari & $11.832889045711607,77.94214015355809$ & Salem \\
\hline 7 & Mallikundam & $11.879409367196567,77.90420896048289$ & Salem \\
\hline 8 & Vazhapadi & $11.656775354146326,78.40187057341394$ & Salem \\
\hline 9 & Ayothiapattinam & $11.678625602423615,78.23288918192901$ & Salem \\
\hline 10 & Mallikarai & $11.578287994955963,78.49669332982101$ & Salem \\
\hline 11 & Attur & $11.601006780799647,78.59691957206958$ & Salem \\
\hline 12 & Singipuram & $11.625408778112208,78.41173586328848$ & Salem \\
\hline 13 & Krishnagiri & $12.527487369732494,78.21500036445342$ & Krishnagiri \\
\hline 14 & Rayakottai & $12.515828521002238,78.03191381220594$ & Krishnagiri \\
\hline 15 & Hosur & $12.748212609908164,77.83581406836144$ & Krishnagiri \\
\hline 16 & Gundalapatti & $12.178115378796399,78.17690314167471$ & Krishnagiri \\
\hline 17 & Bommidi & $11.985749117328707,78.25792730721723$ & Dharamapuri \\
\hline 18 & Thoppur & $11.944101988529056,78.05742683411441$ & Dharamapuri \\
\hline 19 & Kadathur & $12.095210056909767,78.29157293530848$ & Dharamapuri \\
\hline 20 & Papparapatti & $11.52862749255263,78.06841315845728$ & Dharamapuri \\
\hline
\end{tabular}

\section{Morphological and biochemical characterization of NKMV-3.}

The cells of the NKMV-3 strain were Gram positive, motile, short rod-shaped, aerobic bacterium with cell sizes ranging from 1-3 $\mu \mathrm{m}$. The colony of the strain on nutrient agar and Luria Bertani agar was irregular in form with flat elevation and undulate margins. The colour of the colony was dull white with matte texture. NKMV-3 was positive for gelatin liquefaction, catalase and citrate activity. The isolate was able to utilize different sources of carbon namely glucose and sucrose. The isolate was negative for acetoin production (Voges-Proskauer reaction), utilization of mannitol, arabinose and trehalose (Table 4). 
Table 4

Morphological and Biochemical characters of strain NKMV-3

\begin{tabular}{|llll|}
\hline Description & Results & Description & Results \\
\hline Shape & Short Rod & Catalase activity & + \\
\hline Cell size $(\mu \mathrm{m})$ & $1-3 \mu \mathrm{m}$ & Nitrate reduction & + \\
\hline Form of spores & Elliptical & Arginine & + \\
Mobility & + & Sucrose & + \\
Aerobic & + & Mannitol & - \\
\hline Grams Staining & + & Glucose & + \\
\hline Malonate & + & Arabinose & - \\
\hline Voges-Proskauer reaction & - & Trehalose & - \\
\hline Citrate & + & & \\
\hline Gelatin liquefaction & + & & \\
\hline
\end{tabular}

\section{Molecular characterization of 16S rRNA gene of NKMV-3 strain.}

The $16 S$ rRNA gene of strain NKMV-3 was amplified using bacterial universal primers 27F and 1492R. The PCR amplification yielded 1185 nucleotides and sequenced (GenBank accession number:

MZ243468). The nucleotide sequence of NKMV-3 16S rRNA gene showed high similarity (99.58 \%) to the sequence of B.velezensis (Fig. 1). 16S rRNA gene sequence from similar Bacillus species were used for the construction of the phylogenetic tree. NKMV-3 clustered with B. velezensis strainsCBMB205 and FZB42.

Figure 1. Phylogenetic tree based on 16S rRNA gene sequences. The tree was constructed by UPGMA method. Bootstrap values over 50\% (based on 100 replications) are shown at each node. The isolate obtained in the present study is marked with blue symbol.

Antagonistic effects of B. velezensis strain NKMV-3 against major phytopathogens.

A dual culture technique was performed to evaluate the efficacy of NKMV-3 strain against major agricultural phytopathogens (Fig. 2). After 7 days of incubation, NKMV-3 strain was most effective in inhibiting the mycelial growth of $A$. solani with an inhibitory percentage of $58.0 \pm 0.25 \%$. NKMV-3 was ineffective against Macrophomina phaseolina (Table 5). 
Table 5

In vitro antifungal activity of NKMV-3 strain against various phytopathogens on Potato Dextrose Agar Medium

\begin{tabular}{|ll|}
\hline Phytopathogen details & \% Inhibition \\
\hline Alternaria solani & $\mathbf{5 8 . 0} \pm \mathbf{0 . 2 5}$ \\
\hline Fusarium oxysporum f.sp. lycopersici & $49.4 \pm 0.06$ \\
\hline Rhizoctonia solani & $41.3 \pm 0.25$ \\
\hline Pyricularia oryzae & $27.9 \pm 0.06$ \\
\hline Macrophomina phaseolina & $0.4 \pm 0.12$ \\
\hline
\end{tabular}

In vitro effects of crude lipopeptides of B. velezensis NKMV-3 against A. solani.

The inhibitory effect of NKMV-3 crude lipopeptide extract was assessed using poison food technique (Fig. 3). It was observed that a $5 \%$ crude lipopeptides of NKMV-3 strain significantly $(70.8 \pm 1.0)$ inhibited the mycelial growth compared to other tested concentrations (Table 6).

Table 6

In vitro antifungal activity of NKMV-

3 A.solani

\begin{tabular}{|ll|}
\hline $\begin{array}{l}\text { Sample } \\
\text { concentration (\%) }\end{array}$ & \% Inhibition \\
\hline 1 & $9.9 \pm 1.0$ \\
\hline 2 & $13.6 \pm 1.0$ \\
\hline 3 & $29.0 \pm 3.06$ \\
\hline 4 & $58.6 \pm 1.0$ \\
\hline 5 & $70.8 \pm 1.0$ \\
\hline
\end{tabular}

Amplification of Iturin, Fengycin and Surfactin genes from B. velezensis NKMV-3.

Since the crude lipopeptides showed inhibitory effect against $A$. solani. The presence of lipopeptide genes in NKMV-3 namely iturin (ituC), surfactin ( $(f r A)$ and fengycin ( $f e n B$ and $f e n D$ ) were checked by PCR amplification using primers reported in the literature and as describedin the earlier section. Upon PCR amplification, 670 bp corresponding to $s f r A$, fenB and fenD and 594 bp corresponding to ituC were visualized. Thus, all these four lipopeptide genes were present in B. velezensis NKMV-3 (Fig. 4).

\section{Identification of Lipopeptides from B. velezensis NKMV-3 though Reverse Phase - HPLC}

The lipopeptides namely iturin, fengycin and surfactin in crude methanolic extract were separated and identified using a RP-HPLC by comparing its retention time to the specific standards (Sigma, USA). 
Compounds similar to iturin, fengycin and surfactins were isolated with retention times ranging from 4 to $7 \mathrm{~min}, 12$ to $15 \mathrm{~min}$ and 27 to 30 min respectively (Fig. 5).

\section{Structural Analysis of crude lipopeptides from B. velezensis NKMV-3 through FTIR.}

The FTIR analysis for crude lipopeptides is exhibited in Fig. 6 . A broad peak at $3308 \mathrm{~cm}^{-1}$ specifies the existence of $-\mathrm{OH}$ or $-\mathrm{NH}$ groups. FTIR peaks at $2957.79,2871.63$ and $1466.26 \mathrm{~cm}^{-1}$ indicate the existence of the $-\mathrm{C}-\mathrm{H}$ stretching $(-\mathrm{CH} 3$ or $\mathrm{CH} 2$ ) of the aliphatic chain of lipids present in the NKMV-3. The presence of the peptide fraction in sample was revealed by the wavenumbers responsible for amide bond at $603.14, \mathrm{~N}-\mathrm{H}$ bending of the secondary amides at 1542 and 1649.21 of carbonyl group $(\mathrm{C}=0)$. A peak at $1208 \mathrm{~cm}^{-1}$ confirms the presence of $\mathrm{C}-\mathrm{O}$ bending of esters in the NKMV-3.

\section{Effects of crude lipopeptides against A. solani in detached tomato leaves.}

The inhibitory effect of various concentrations of NKMV-3 crude lipopeptide against $A$. solani was assessed using detached tomato leaf bioassay(Fig. 7). There was an evident reduction of lesion diameter with increase in concentration of the crude lipopeptides. $5 \%$ crude lipopeptides showed maximum reduction in lesion diameter $(0.4 \pm 0.32 \%)$ in comparison to control (Fig. 8).Lesion diameter observed after 7 days after incubation.

Values are averages of three replicates. Bars represent means from replicates, and error bars represent standard errors. Differentletters indicate significant differences between different treatments according to Tukey'stest $(a=0.05)$

\section{Discussion}

Early Blight of Tomato has become an economically important disease both under field conditions and also under storage of tomato fruits $[39,40]$, thus garnering interest from both field pathologists and also from post-harvest disease control specialists. Several synthetic fungicides have been used by farmers for the control of early blight of Tomato [42]. But, due to their continuous usage and also non-adherence to prescribed dosages, resistance build-upof resistance has been observed [43] among the pathogens. Hence, a safe and sustainable method of disease control is the need of the hour. Soil samples from 20 different tomato growing regions of the state of Tamil Nadu, India was used for the isolation of 146 bacterial antagonistic bacteria in this study. Among them, NKMV-3 was found inhibit $A$. solani with highest percent of inhibition. Many species of the genus Bacillus are known to exhibit antifungal activity against various plant pathogens especially against $A$.solani $[1,44]$.

Strain NKMV-3 was identified as $B$. velezensis, based on morphological, biochemical and 16S rRNA gene sequencing. $B$. velazensis is a farmer friendly bacterium reported to promote plant growth [45], control plant diseases $[46,47]$ and detoxify pollutants [48]. Several $B$. velezensis isolates were found to effectively control various Phyto-pathogens such as Botrytis cinerea, Alternaria solani, Fusarium oxysporum, Colletotrichum gloeosporioidesamong others [49]. B. velezensis has already been reported to 
control R. solanacearum, F. oxysporum and Verticillium dahlia infecting tomato plant $[21,50]$. This research articles is the first report of a $B$. velezensis strain isolated from major tomato growing regions of Tamil Nadu, India which is effective against $A$. solani.

Dual-culture results showed $B$. velezensis NKMV-3 not only inhibit the growth of $A$. solani, also inhibited other two tomato pathogens, F. oxysporumf.sp. lycopersciand $R$. solani. These results suggest that $B$. velezensis NKMV-3 could control not only early blight but also vascular wilt and foot rot diseases in tomato. These were tested at the laboratory scale, the efficacy of $B$. velezensis on the field against other tomato diseases will be studied in future.

To further understand the biocontrol mechanism of B. velezensis NKMV-3, A. solani was used as an indicator. We confirmed the presence of essential genes for lipopeptides secretion namely, iturins, fengycin and surfactinsin B. velezensis NKMV-3 by PCR amplification. The presence of all the three secreted lipopeptides were identified through RP-HPLC and FTIR analyses. To date, lipopeptides secreted by $B$. velezensis have been documented to inhibit the growth of phytopathogens, such as $R$. solani, $F$. oxysporum, A. flavus and Ralstonia solanacearum[19]. In our findings, $5 \%$ crude lipopeptide extract effectively inhibited $A$. solani as evidenced by both poison plate technique and detached leaf assay.Chen et al., 2018 showed the lipopeptides secreted by B. velezensis LM2303 inhibited F. graminearum by damaging the cell membrane permeability. The same mechanism could also work in $A$. solani, this will be tested in future.

\section{Conclusion}

This study clearly revealed the biocontrol potential of B. velezensis strain NKMV-3 isolated from the tomato growing regions of Tamil Nadu. In vitro investigations through lipopeptide biosynthesis gene detection, RP-HPLC, FTIR analysis and antifungal activities clearly demonstrated its ability to be used as a biocontrol agent for controlling fungal pathogens. The commercialization of the product could be possible with formulations and field trials in future.

\section{Declarations}

\section{Conflict of interest}

There is no conflict of interest to this work

\section{Ethical Approval}

Not applicable

\section{Consent to Participate}

Not applicable 


\section{Consent to Publish}

Not applicable

\section{Authors Contributions}

VM: data acquisition, manuscript writing; BNV: data analysis; DM: proofreading; characterization and SRM: project guidance and correspondence.

\section{Funding}

Not applicable

\section{Availability of data and materials}

Not applicable

\section{References}

1. Awan, Z. A., Shoaib, A. (2019). Curr. Plant Biol., 20, 100125. https://doi.org/10.1016/j.cpb.2019.100125

2. Rubén, D., Gullon, P., Pateiro, M., Munekata, P. E. S., Zhang, W., Lorenzo, J. M. (2020). Antioxidants, 9(1), 73.

3. Viuda-Martos, M., Sanchez-Zapata, E., Sayas-Barberá, E., Sendra, E., Pérez-Álvarez, J. A., FernándezLópez, J. (2014). Critical Rev. Food Sci. Nutri. 54(8), 1032-1049. https://doi.org/10.1080/10408398.2011.623799

4. Garg, S., Ram Kumar, D., Yadav, S., Kumar, M., Yadav, J. (2020). Acta Scienti. Agri., 4(11), 08-15. https://doi.org/10.31080/asag.2020.04.0908

5. Adhikari, P., Oh, Y., Panthee, D. R. (2017, October 1). Inter J. Mole. Sci. https://doi.org/10.3390/ijms18102019

6. Muthu-Pandian Chanthini, K., Senthil-Nathan, S., Soranam, R., Thanigaivel, A., Karthi, S., Sreenath Kumar, C., Kanagaraj Murali-Baskaran, R. (2019). Arc. Phytopath. Plant Prot. https://doi.org/10.1080/03235408.2018.1496525

7. Biswas, S. (2016). Integrated Disease Management of Early Blight In Tomato caused by Alternaria solani Sorauer.

8. Chavan, V. A., Borkar, S. G. (2020). Strate GSC Biological Pharma. Sci., 12(3), 180-188. https://doi.org/10.30574/gscbps.2020.12.3.0280

9. Bauske, M. J., Gudmestad, N. C. (2018). Plant Disease, 102(3), 666-673. https://doi.org/10.1094/PDIS-08-17-1268-RE

10. Hassaan, M. A., El Nemr, A. (2020). Egyptian J. Aquatic Res.. https://doi.org/10.1016/j.ejar.2020.08.007 
11. Tudi, M., Ruan, H. D., Wang, L., Lyu, J., Sadler, R., Connell, D., Phung, D. T. (2021). Inter. J. Environ. Res. Public Health. https://doi.org/10.3390/ijerph18031112

12. Hobbelen, P. H. F., Paveley, N. D., Van Den Bosch, F. (2014). PLoS ONE, 9(3), 91910. https://doi.org/10.1371/journal.pone.0091910

13. Baibakova, E. V., Nefedjeva, E. E., Suska-Malawska, M., Wilk, M., Sevriukova, G. A., \&Zheltobriukhov, V. F. (2019). Annual Res. Rev. Biol. 32(3), 1-16. https://doi.org/10.9734/arrb/2019/v32i330083

14. Hollomon, D. W. (2015). Plant Prot. Sci. 51(4), 170-176. https://doi.org/10.17221/42/2015-PPS

15. Köhl, J., Kolnaar, R., Ravensberg, W. J. (2019). Frontiers Plant Sci. https://doi.org/10.3389/fpls.2019.00845

16. Heydari, A., Pessarakli, M. (2010). J. Biol. Sci. https://doi.org/10.3923/jbs.2010.273.290

17. Shafi, J., Tian, H., Ji, M. (2017). Biotechnol. Biotech. Equip., https://doi.org/10.1080/13102818.2017.1286950

18. Andrić, S., Meyer, T., Ongena, M. (2020). Frontiers Microbiol. https://doi.org/10.3389/fmicb.2020.01350

19. Rabbee, M. F., Baek, K.-H. (2020). Molecules, 25(21). https://doi.org/10.3390/MOLECULES25214973

20. Fan, B., Wang, C., Song, X., Ding, X., Wu, L., Wu, H., Borriss, R. (2018). Frontier Microbiol. https://doi.org/10.3389/fmicb.2018.02491

21. Chen, M., Wang, J., Liu, B., Zhu, Y., Xiao, R., Yang, W., Chen, Z. (2020). BMC Microbiol., 20(1), 1-12. https://doi.org/10.1186/s12866-020-01851-2

22. Choi, T. G., Maung, C. E. H., Lee, D. R., Henry, A. B., Lee, Y. S., Kim, K. Y. (2020). Biocontrol Sci. Technol., 30(7), 685-700. https://doi.org/10.1080/09583157.2020.1765980

23. Xiang, N., Lawrence, K. S., Kloepper, J. W., Donald, P. A., Mclnroy, J. A., Lawrence, G. W. (2017). Plant Disease, 101(5), 774-784. https://doi.org/10.1094/PDIS-09-16-1369-RE

24. Shanmugam, V., Atri, K., Gupta, S., Kanoujia, N., Naruka, D. S. (2011). Folia Microbiologica, 56(2), 170-177. https://doi.org/10.1007/s12223-011-0031-3

25. Pane, C., Zaccardelli, M. (2015). Biological Control, 84, 11-18. https://doi.org/10.1016/j.biocontrol.2015.01.005

26. Etebarian, H.-R., Sholberg, P. L., Eastwell, K. C., Sayler, R. J. (2005). Can. J. Microbiol. 51(7), 591-598. https://doi.org/10.1139/w05-039

27. Bergey, D., \& John, G. H. (1994). Bergey's manual of determinative bacteriology (9th ed.). Williams \& Wilkins.

28. White, T. J., Bruns, T. D., Lee, S. B., \& Taylor, J. W. (1990). PCR protocols: a guide to methods and applications. (M. A. Innis, Ed.). San Diego: Academic Press.

29. Zhu, J., Tan, T., Shen, A., Yang, X., Yu, Y., Gao, C., ... Zeng, L. (2020). J. Plant Pathol. 102(2), 433-441. https://doi.org/10.1007/s42161-019-00457-6

30. Kumar, S., Stecher, G., \& Tamura, K. (2016). Molecular Biol. Evol. 33(7), 1870-1874. https://doi.org/10.1093/molbev/msw054 
31. Li, Z., Guo, B., Wan, K., Cong, M., Huang, H., \& Ge, Y. (2015). Biotechnol. Biotechnol. Equip. 29(6), 1062-1068. https://doi.org/10.1080/13102818.2015.1068135

32. Chung, S., Kong, H., Buyer, J. S., Lakshman, D. K., Lydon, J., Kim, S.-D., Roberts, D. P. (2008). Appl.Microbiol. Biotechnol. 80(1), 115-123. https://doi.org/10.1007/s00253-008-1520-4

33. Płaza, G., Chojniak, J., Rudnicka, K., Paraszkiewicz, K., Bernat, P. (2015). J. Appl. Microbiol., 119(4), 1023-1034. https://doi.org/10.1111/jam.12893

34. Lin, L.-Z., Zheng, Q.-W., Wei, T., Zhang, Z.-Q., Zhao, C.-F., Zhong, H., Guo, L.-Q. (2020). Frontiers Microbiol. 11, 579621. https://doi.org/10.3389/fmicb.2020.579621

35. Zouari, I., Jlaiel, L., Tounsi, S., Trigui, M. (2016). Biological Control, 100, 54-62. https://doi.org/10.1016/j.biocontrol.2016.05.012

36. Dhanarajan, G., Rangarajan, V., Sridhar, P. R., Sen, R. (2016). ACS Sustain. Chem. Engin., 4(12), 66386646. https://doi.org/10.1021/acssuschemeng.6b01498

37. Sharma, D., Ansari, M. J., Gupta, S., Al Ghamdi, A., Pruthi, P., Pruthi, V. (2015). Jundishapur J. Microbiol., 8(9). https://doi.org/10.5812/jjm.21257

38. Ali, G. S., El-Sayed, A. S. A., Patel, J. S., Green, K. B., Ali, M., Brennan, M., Norman, D. (2016). Appl. Environ. Microbiol. 82(2), 478-490. https://doi.org/10.1128/AEM.02662-15

39. Pansuriya, D., Poonam, P. S., Mohammed, F., Dipen, D. (2021). 10(5), 1423-1428.

40. Tomer, A., Uday Kiran Reddy, C., Diwivedi, S. K. (n.d.). European J. Molecular Clinical Med.

41. Dhaval, P., Faraaz, M., Dholu, D., Shete, P. P. (2021). The Pharma Inno. J., 10(5), 1423-1428.

42. Deshmukh, Cd, D., Pb, K., Pr, B. (2020). J. Pharma. Phytochem., 9(6), 1986-1989.

43. Akram, S., Umar, U. ud D., Atiq, R., Tariq, A., Mahmood, M. A., Ateeq-ur-Rehman. (2018). Pak.J. Life Social Sci.16(2), 117-123.

44. Zhang, D., Yu, S., Yang, Y., Zhang, J., Zhao, D., Pan, Y., ... Zhu, J. (2020). Frontiers Microbiol. 11. https://doi.org/10.3389/fmicb.2020.01196

45. Meng, Q., Jiang, H., Hao, J. J. (2016). Biological Control, 98, 18-26.

https://doi.org/10.1016/j.biocontrol.2016.03.010

46. Cui, L., Yang, C., Wei, L., Li, T., Chen, X. (2020). Biological Control, 141, 104156. https://doi.org/10.1016/j.biocontrol.2019.104156

47. Nam, M. H., Park, M. S., Kim, H. G., Yoo, S. J. (2009). J. Microbiol.Biotechnol., 19(5), 520-524. https://doi.org/10.4014/jmb.0805.333

48. Bafana, A., Chakrabarti, T., Devi, S. S. (2008). Appl. Microbiol. Biotechnol. 77(5), 1139-1144. https://doi.org/10.1007/s00253-007-1212-5

49. Wang, C., Zhao, D., Qi, G., Mao, Z., Hu, X., Du, B., ... Ding, Y. (2020). Frontiers Microbiol. 10, 2889. https://doi.org/10.3389/fmicb.2019.02889

50. Dhouib, H., Zouari, I., Ben Abdallah, D., Belbahri, L., Taktak, W., Triki, M. A., Tounsi, S. (2019). Biological Control, 139, 104092. https://doi.org/10.1016/j.biocontrol.2019.104092 
51. Chen, L., Heng, J., Qin, S., Bian, K. (2018). PLoS ONE, 13(6), e0198560. https://doi.org/10.1371/journal.pone.0198560

Figures

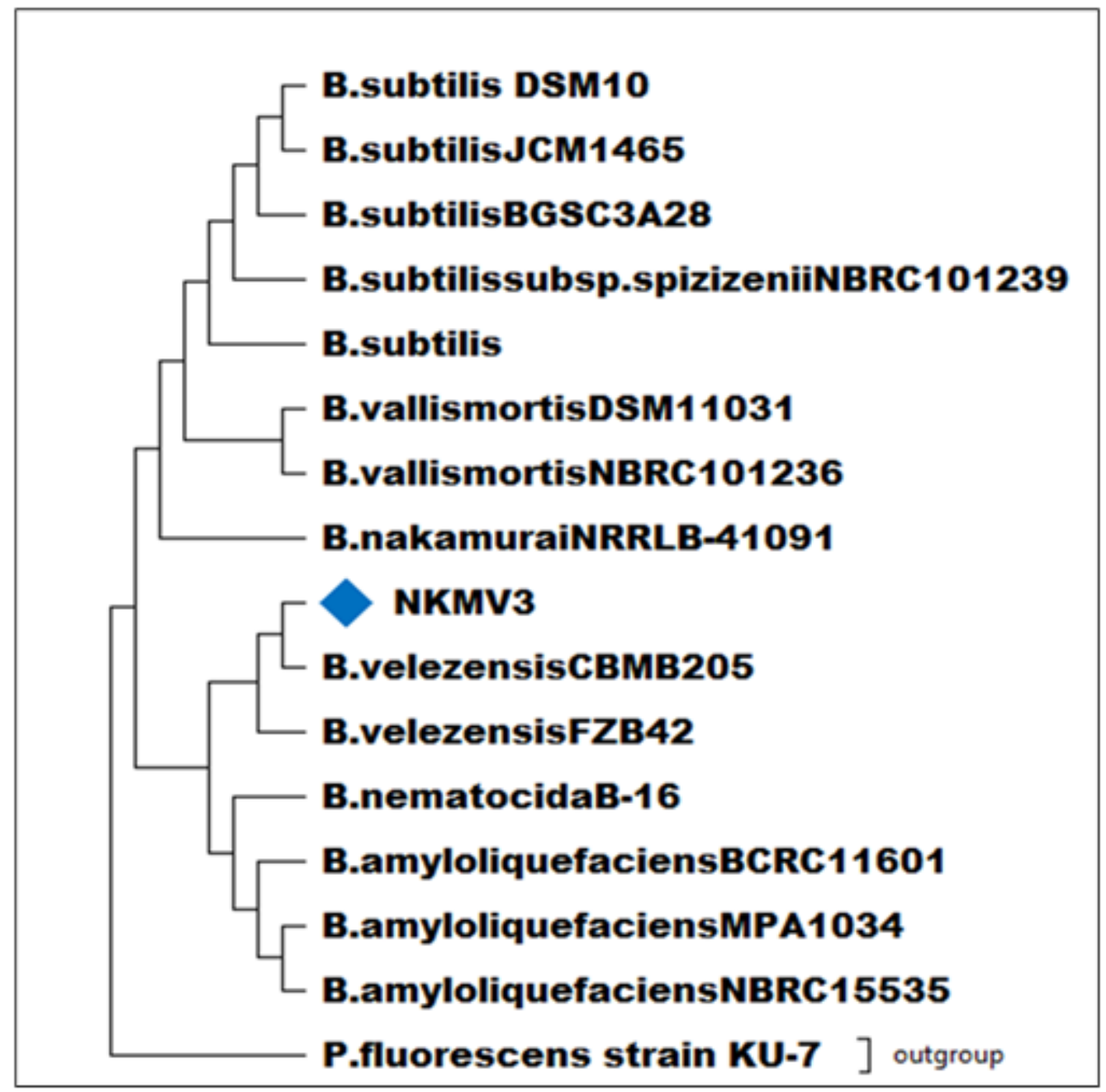

Figure 1

Phylogenetic tree of the B.velezensis NKMV-3 strain based on 16S rRNAsequence analysis constructedusing the neighbor-joiningmethod 

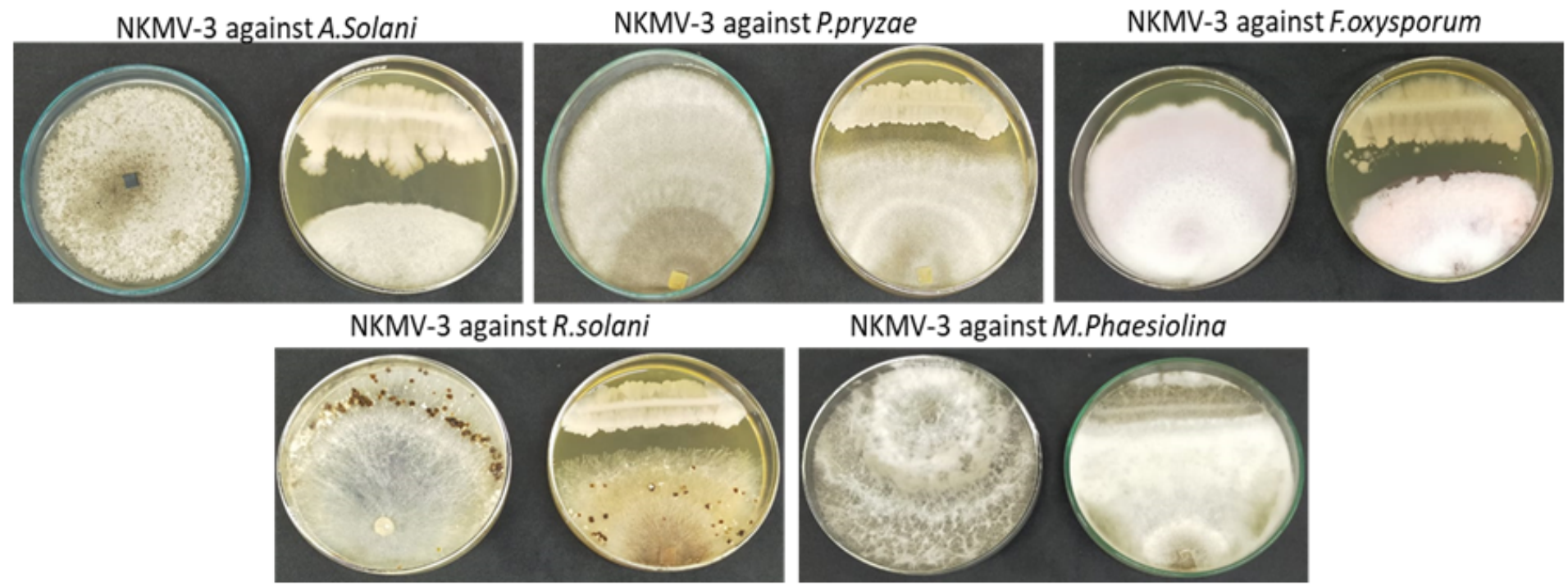

NKMV-3 against M.Phaesiolina

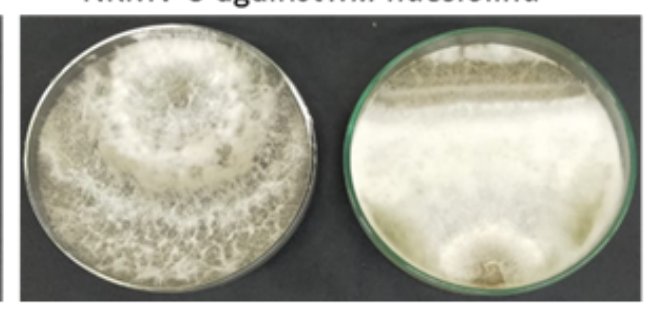

\section{Figure 2}

Invitro Antagonistic activity of B.velezensis strain NKMV-3 against various phytopathogens

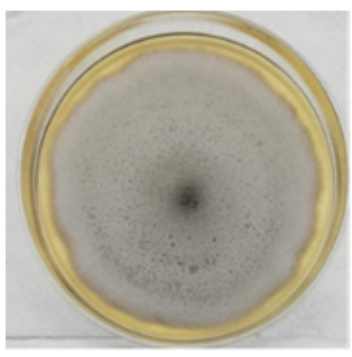

A.Solani - PDA

Control Plate

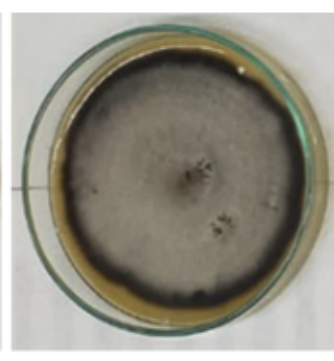

PDA- $1 \%$ Crude NKMV-3 Lipopeptide

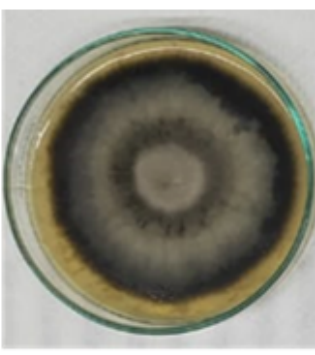

PDA- $2 \%$ Crude NKMV-3 Lipopeptide

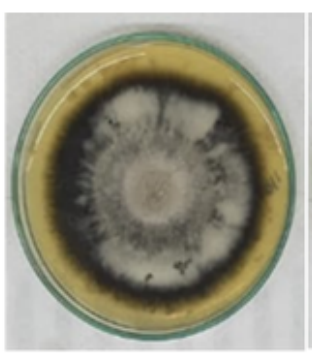

PDA- 3 \% Crude NKMV-3 Lipopeptide

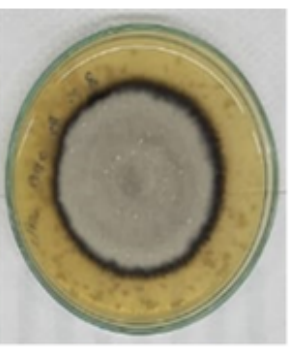

PDA- $4 \%$ Crude NKMV-3 Lipopeptide

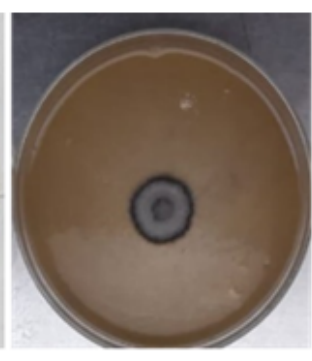

PDA- $5 \%$ Crude NKMV-3 Lipopeptide

Figure 3

Invitro effect of various concentrations of the crude lipopeptides against A.solani 


\section{$\begin{array}{lllll}M & 1 & 2 & 3 & 4\end{array}$}

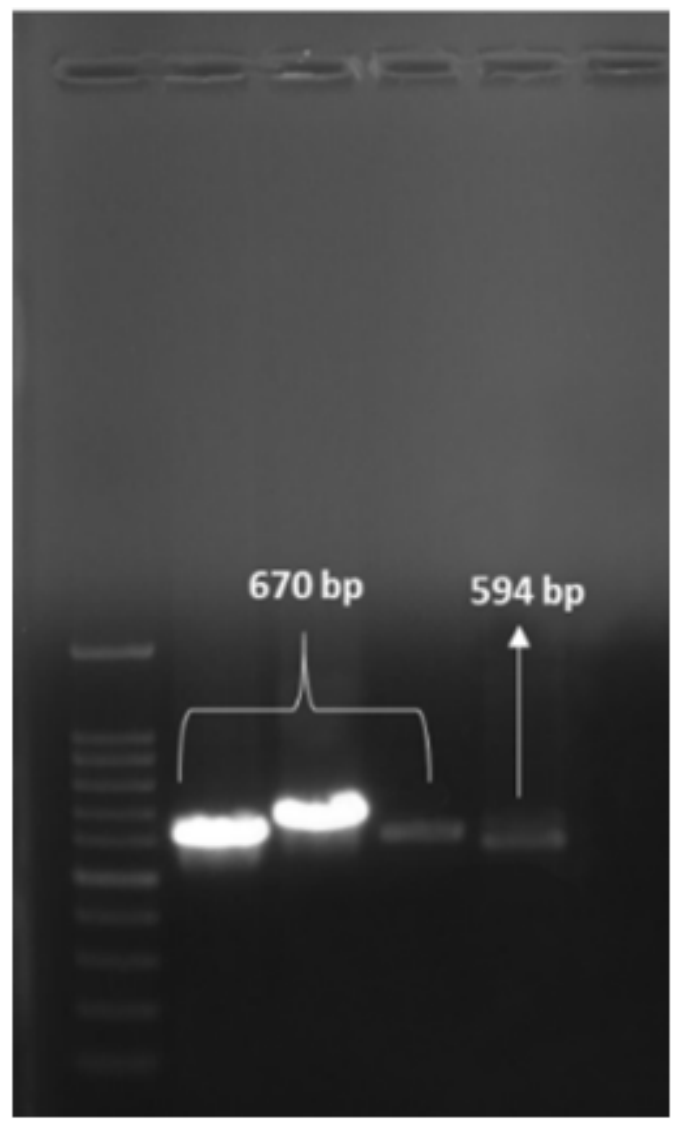

Figure 4

PCR amplification of crude lipopeptide genes from B.velezensis strain NKMV-3. Agarose gel Electrophoresis of PCR products for the genes of (1) Surfactin: Sfr A, (2,3) Fengycin: fen b, fen D and (4) Iturin: ItuC of NKMV-3 strain, M: 1000 bp DNA ladder 

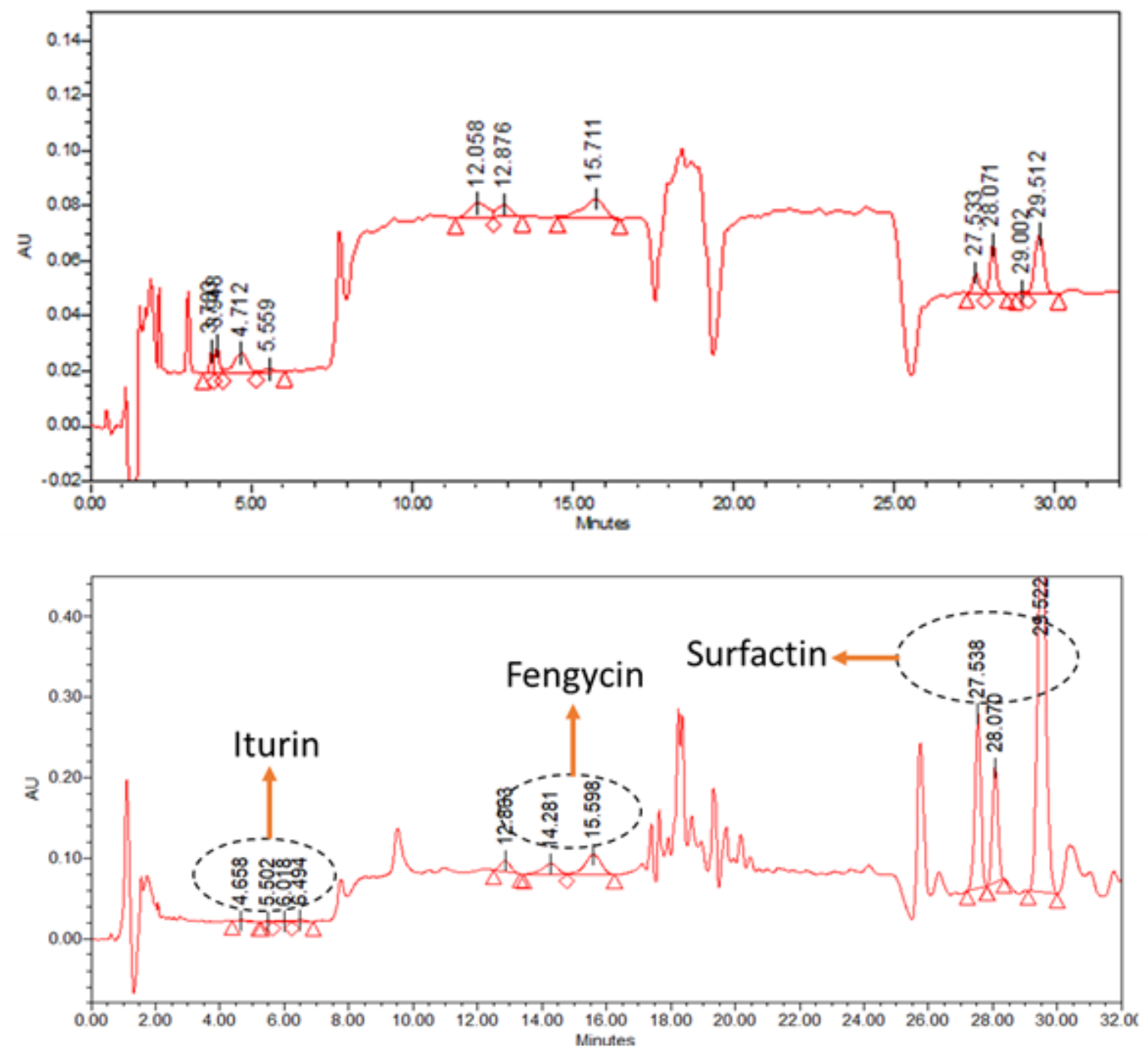

\section{Figure 5}

High-performance liquidchromatography (HPLC) profileof crude lipopeptides fromB. velezensis NKMV-3. The crude lipopeptide extract exhibited fractions consisting of Iturin, Fengycin and Surfactin 


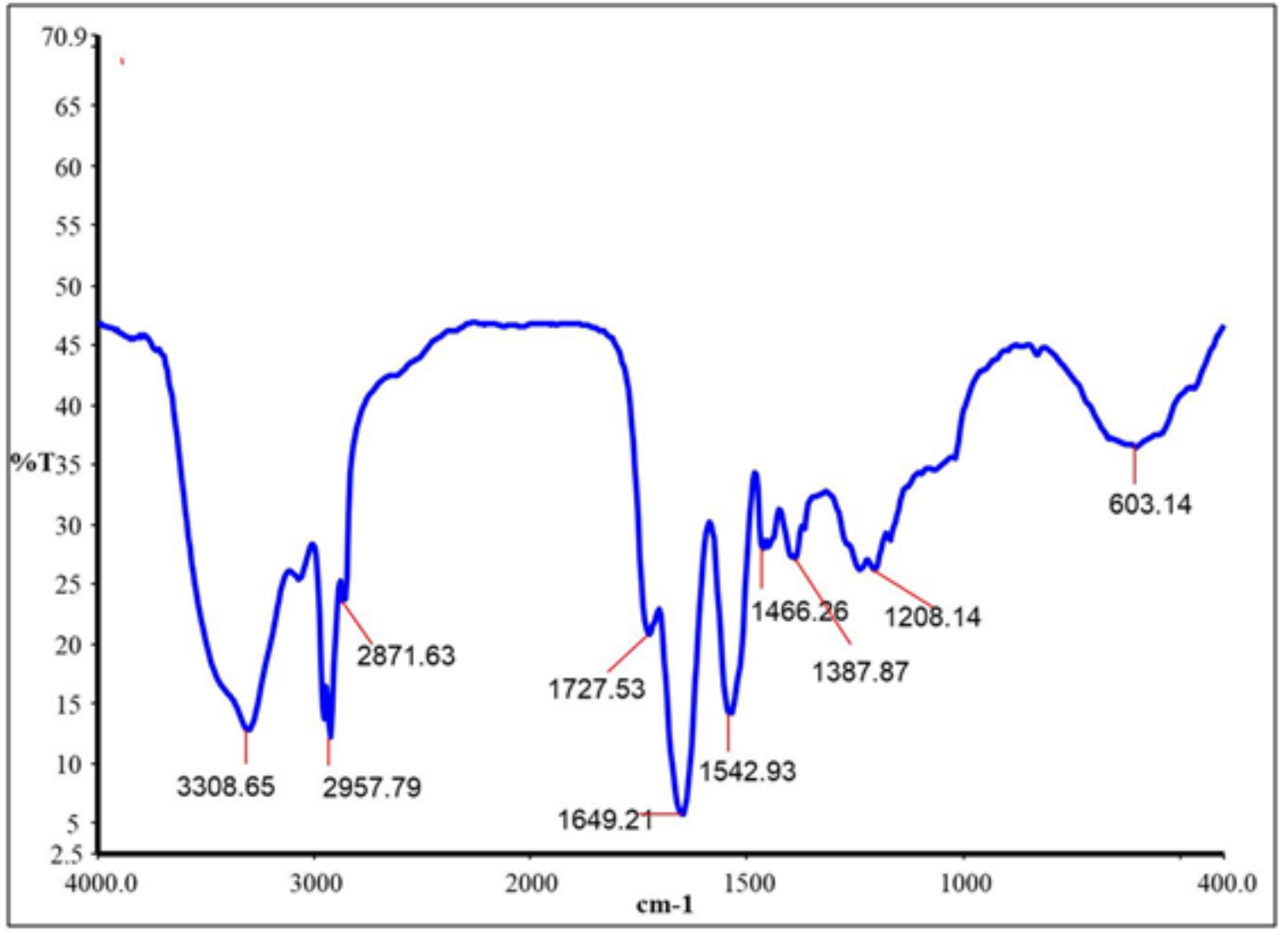

Figure 6

FTIR analysis of Lipopeptide extract from B. velezensisstrain NKMV-3

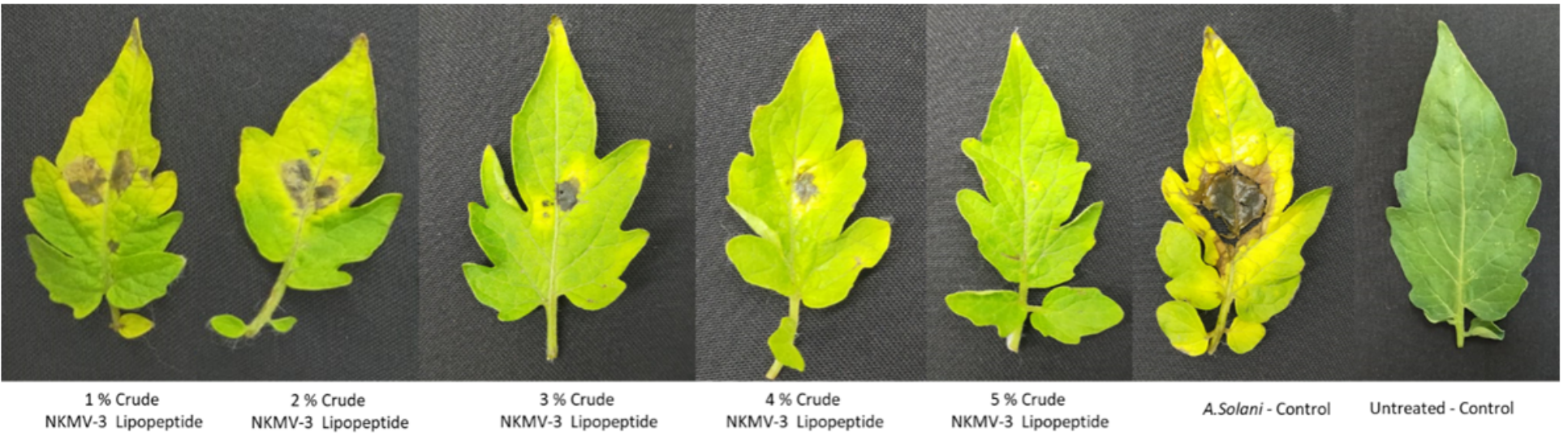

Figure 7

Detached leaf bioassay of crude lipopeptides from B.velezensis strain NKMV-3 against A.solani 


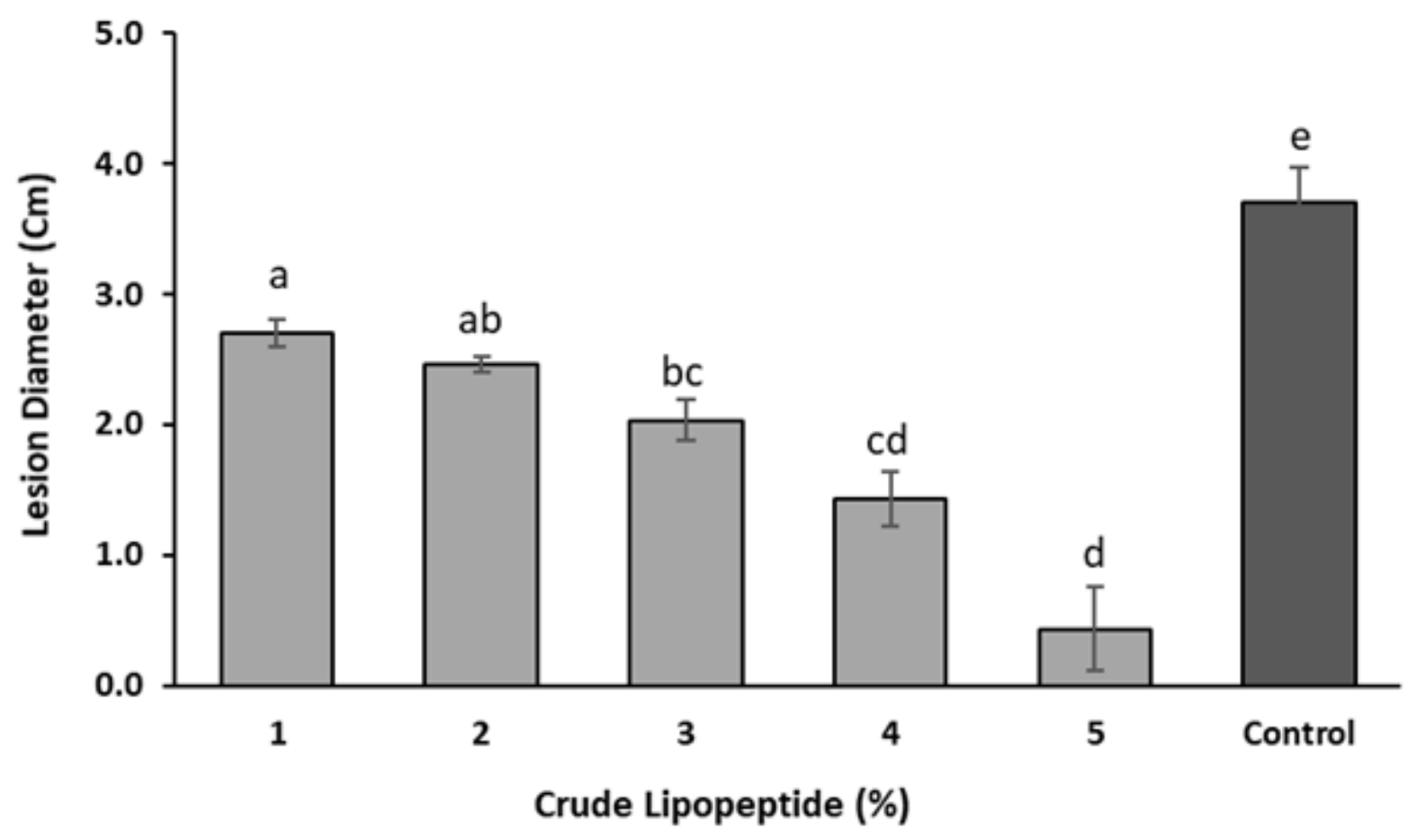

Figure 8

Lesion diameter of detached leaf bioassay of crude lipopeptides from B.velezensis strain NKMV-3 against A.solani 